We do not possess biographical information about Ioane, the bishop of Bolnisi. The only thing known about him is that he was a contemporary of King Bagrat III (980-1014). In different sources there is mention of one Ioane Khakhuleli, who flourished in the same era and who is known to be an eloquent preacher called even "Oqropiri", that is to say, the Golden Mouth. It is possible that he is identical with Ioane Bolneli, for the name of the latter was also renowned for eloquent homilies of its bearer. If this is true, then Ioane, after having held the Bolinisi see, was entrusted with the Khakhuli see, which he abandoned for Mt. Athos in 1019. Perhaps this explains the fact that some of Ioane Bolneli's sermons are preserved in an Athonite manuscript of the tenth-eleventh century. So far thirteen original sermons of Ioane Bolneli have been discovered in various manuscripts. (See above, p. 285, n. 73, for the reference to the Georgian edition.)

\title{
THE WORD SPOKEN BY JOHN THE BISHOP OF BOLNISI CONCERNING THE CONSECRATION OF THE HOLY CHURCHES WHICH WAS CONDUCTED IN JERUSALEM
}

\author{
Translated by Levan Gigineishvili (Tbilisi, Georgia)
}

Today the heavens rejoice and the earth is joyful, and [joyful are] the sea and all that is therein. Today rejoices the Holy Church, [the Church of] the resurrection of our Lord Jesus Christ and with it rejoice all the Holy Churches, for in this month, on September 13, is conducted the consecration of this Holy Church of the Resurrection, and on the fourteenth of the same month is conducted the consecration of the Holy Catholic Apostolic Church, which were built by the Emperor Constantine. And on the same day there was a vision and worship of the venerable Cross, on which our Lord Jesus Christ was hanged for our salvation.

And on the fifteenth of the same month is conducted the consecration of the Holy and Glorious Sion, which is the mother of all churches, which was established by the Holy Apostles, and Theodosius the Great built, magnified and glorified it, in which [church] the Holy Ghost descended (just like in the mystery of the tongues of flames of fire on the holy day of Pentecost in the same holy house, in which [fire] spread upon the holy Apostles, through which they were filled with 
the grace of the Holy Spirit) and joyfully cried and said: raise the voice of praise in Sion and give glory to God in it, for this is the mother of all churches, upon which the Holy Spirit descended and in which He (the Spirit) dwelled. And now all creation rejoices in the consecration of the Holy Churches.

Today are fulfilled the sayings of the prophets: "all the nations which Thou have created will come and worship Thee, o Lord, and will glorify Thy name, and no more [only] Israel will come to worship Thee, neither all the Jews, but all the nations, which Thou have created, will come and worship Thee o Lord, and glorify Thy name". And similar to those [words]: "There will ascend nations of the Lord, for bearing witness to Israel, and for proclaiming the name of the Lord."

And St. Apostle Paul attests to all those [prophetic sayings] and says that "to the name of Jesus Christ all knees will bend in heaven and on earth and in hell and all will witness that the Lord Jesus Christ is the one whom God the Father glorifies"1 Amen.

And now you, the beloved, who are borne by this "barren one," the Holy Church, all you who are from other nations and of different languages, all the nations that are bought by our Lord Jesus Christ through His blood, now, let us come and ascend to the consecration of those Holy Churches. Let us enter its chambers and worship this place, where His feet stood, where there was the peace of the Cross and the building of those powerful fortresses - His Holy Churches.

And, we, with the superabundance of His mercy shall enter into His house and say together with His psalmist: "and worship Thy Holy Temple in Thy fear," yet, this is not the temple of the gathering of the Jews, for the place of the gathering of the Jews (i.e. the Temple), that had a multitude of children, weakened, it was ruined so that not a stone remained on stone, according to the words of the Lord, but we worship this present Temple, the Church of the gentiles (pagans), that first was barren, but now has begotten many children, which the Holy Scripture bears witness to: "Rejoice thou, o barren one, who could not beget, rise and cry aloud: for more are the children of the widow than of the one who had a husband." (cf. Is. 54:1).

(1) Here is a modified interpretation of a Pauline text in Phil. 2:10-11. Actually, Paul says that "all will witness that Jesus Christ is Lord to the glory of God the Father" (i.e. unless one affirms the divinity of Christ, one cannot glorify the Father). 
I speak about this temple, which the Holy Church has now built, and to which the Holy Gospel bears witness and says: "When our Lord came to the places of Caesarea of Philip, He summoned His disciples and asked them: 'Whom do the people think the Son of Man is?'" (cf. Matt. 16:13). Oh, mysterious and magnificent and inscrutable mystery of the Divinity! What, did not He know what the people spoke about Him, He who knows the hearts and kidneys of men and all their thoughts? So, why does He then ask the disciples and say: 'Whom do the people think the Son of Man is?' But, the question which He puts to the disciples, was the same question he put initially to Adam in Paradise: "Where art thou Adam?" Did He not know where he was? Yet, still He asks and says: "Where art thou, Adam?" and the latter answers and says: "I heard Thy voice, as Thou proceeded through paradise, and I was afraid, for I was naked, and I hid myself". And again, He asks Cain, "Where is Abel, thy brother?" And to Adam: "Who told thee that thou wast naked? Hast thou eaten of the tree, from which I have commanded thee not to eat?" And to Cain He says: "The voice of the blood of Abel, thy brother, crieth from the ground unto Me". If He knew that Adam had eaten from that tree and had hid himself, and that Cain had killed his brother and hid himself, then He knew all these things; and similarly He asks Abraham in the tent and says: "Where is Sarah, thy wife?", and also asks Elijah: "What doest thou here, Elijah?" Abraham answers Him concerning his wife: "Here she is, in the tent," and Elijah testifies about Israel and says: "O, Lord, Thy prophets have been slain, Thy altars have been thrown down, and only I am left and they seek my soul." And what response does the Lord give to him? "I have retained for myself seven thousand men, who did not bend their knees unto Baal." And the first saying is similar to the last: He asks Adam: "Adam, Adam where art thou?" and to Cain "Where is thy brother?" and to Abraham "Where is Sarah, thy wife?" and He tests Elijah and says "What doest thou here, Elijah?" And here, now, when He appeared on the earth and dwelled among men, He asks His disciples and says: 'Whom do the people think the Son of Man is?' and they answered: "[Some say that Thou art] John the Baptist, others say that Thou art Elias, still others say that Thou art Jeremias or one of the prophets". Whom did the disciples imply by saying 'or one of the prophets?' In fact, they (i.e. the people) thought Him to be Moses and said: "Could He be Moses, one of the prophets?" Then Jesus asked them: "And what say ye concerning Me, who am I? Ye, who see the raising of the dead, the cleansing of lepers, the 
healing of the paralytic, what do ye say of Me, who am I?" And then the disciples turned sober and looked at each other marveling, and meditated in their hearts as to what answer they should give to Him. And then all of them, as if with a single face, looked at the Apostle Peter, as at their leader, and the head of the Apostles, as the elder and the wise, as the prophet and truly a prophet and even greater and more than a prophet, for the Apostles were greater than prophets, as also Paul says: first Apostles and then prophets. So, as they meditated, the Apostle Peter was filled with the Holy Spirit, with the Grace from Above, and said unto the Lord: "Thou art the Christ, the Son of the Living God," for which he attained blessedness. And then Jesus told him: "Blessed art thou, Simon, the son of Jonah, for not flesh and blood, but my Father which is in Heaven hast revealed this to you, and also I say to you: thou art a rock and upon this rock I will build my Church and the council of Hell shall not prevail against it. Because thou art an unshakeable measure and on this unshakeable measure I will build my Church and the council of hell shall not prevail against it. For thou art a pillar, built and erected, and on this pillar, I will build my Church and the council of hell shall not prevail against it; for thou art the unshakeable faith, and on this unshakeable faith I will build my Church and the council of hell shall not prevail against it. And not only this shall I do, but I will also give unto thee the keys of the Heavens, and whatsoever thou shalt bind on earth, shall be bound also in the Heavens, and whatsoever thou shalt loose on earth, shall be loosed also in the Heavens."

Do you see, the great and wonderful and ineffable philanthropy of the Son of God? For, He entrusts His Heavens to men? [Before] He entrusted the house of Israel to Moses, but now He hated this house and said: "I have hated this nation and said: they permanently err in their hearts and they could not understand my ways. As I have sworn, due to my rage, they will not enter into my repose." He entrusted the tent of the covenant and the ark of the Law to Aaron the Priest and all the Levites, which is abolished now; he entrusted the Temple of the Lord to Solomon, which later the Jews turned into a den of thieves, as the Lord himself says: "The house of My Father shall be called the 'House of Prayer' and ye have made it a den of thieves," which after Him was ruined so that not a stone remained on stone, according to the words of the Lord. But this [Church he entrusts to] the Holy Apostle Peter, the leader of Churches, the unshakeable rock, the fundament that does not quake, the pillar and fortification of the Churches, that is built not 
for Jews, but for all the gentiles (pagans). This Church did the Lord entrust to His beloved disciple and gave to him also the keys of the Heavens, and gave to him and together with him to all the bishops and priests authority and told them: "Whatsoever thou shalt bind on earth, shall be bound also in the Heavens, and whatsoever thou shalt loose on earth, shall be loosed in the Heavens; and whose soever sins ye remit, they are remitted, and whose soever sins ye retain, they are retained."

Then Jesus asks his disciples not to tell anybody that he is the Christ.

Why does He command His disciples not to tell anybody that $\mathrm{He}$ is the Christ? Yet, here the same thing happens as happened when they were descending from Mount Tabor, when He commanded Peter, James and John: "Tell nobody what you have seen, until the Son of the Man be risen from the dead." And again, when He cleansed the leper, He told him: "Behold, let nobody know what the Lord hath done for thee and how He hath helped thee, but go and show thyself to the priest and offer that sacrifice for thy cleansing that Moses commanded, for a testimony unto them". And there are many other passages like this in the Holy Gospels. And let us hasten and come for that purpose, for which we have gathered here: the consecration of those Holy Churches. Before I have spoken about the new consecration, but from now on I shall speak about the [feast of consecration] of the old Temple, built by King Solomon, which John the Evangelist bears witness to and says: "There was [the feast] of the dedication in Jerusalem and it was winter and Jesus was coming and going from the Temple and the porch of Solomon".

Of which dedication [does John speak here]? This was the consecration of the Temple built by Solomon. And what about the winter? Actually, the winter here signifies the winter of great disbelief, and 'Jesus was coming and going from the Temple and the porch of Solomon,' and it was a great winter of the disbelief of the nation. The Jews surrounded our Lord Jesus and told Him: "How long dost thou exasperate us, if thou be the Christ, then tell us plainly," however in this present consecration of the Holy Churches all the gentiles (pagans) cry and say: "Thou art the Christ, the Son of the living God" and "Have mercy upon us." While there the Lord responds to the Jews and says: "I told you and you believed me not. The works that I do in the name of My Father, they bear witness of Me. It was meet for thee to hearken to My words, it was meet for thee to obey My teachings, it was meet 
for thee to come closer to Me. I have come to thee and thou received Me not, and neither didst thou believe Me, because thou art not from My sheep, the pagans who knew me not, they believed and heard My voice, for they are from My sheep. My sheep will hear My voice and will follow Me; My sheep will hear My voice and worship Me and I shall give them eternal life and will not ever let them perish and nobody will take them from My hands! My Father, who gave them to Me, is greater than anybody and nobody will take them from the hands of My Father. I and My Father are one."

As the Jews heard of their ruin and the acceptance of the gentiles (pagans) they took up stones in order to stone him.

Now look, at the consecration of the old Temple they are ready to stone our Lord, but at the present new consecration of the Holy Church all the gentiles (pagans) cry out and say: "Shed Thy Holy Spirit upon this Temple, cleanse it with the Grace of Thy Holy Spirit, so that it may become the healer of our souls and bodies, to us who now hasten to, and glorify and supplicate and worship Thee and conduct this consecration and cry: 'save us, our God, for Thou only are the Holy, the Savior, and Purifier of us all.'

Our Lord answered the Jews: "I have shown you many good works from My Father; for which of them are ye going to stone Me? Haven't I raised the dead; haven't I made thy blind see; haven't I cleansed thy lepers, made the crippled walk and many other things have I done in front of you, for which of them do ye intend now to stone me?" And they responded: "We are not going to stone thee for good works, but for blasphemy: because thou art a man and makest thyself God."

Why are you going to stone Him for the reason that He said 'I am the Son of God,' O Jews? If you do not believe Him, then listen the voice from Above upon the Jordan river: "This is My beloved Son, in whom I am well pleased". And another voice on holy Tabor: "This is my beloved Son, in whom I am well pleased. Hear ye Him." Either listen to the words said by the Father from above upon the Jordan river, or the second witnessing upon holy Tabor, or listen to the third voice that came like thunder and said: "I have glorified Thee and will glorify Thee again." And if you do not believe those three witnesses of the divine voice that came from above, then listen to the witness of your father the devil, when He exorcized the Legion, and they were telling Him: "O, Jesus, the Son of God, why have Thou come before the time to destroy us? We know who Thou art, the Holy one of God." 
If the devils believe [that He is the Son of God] and tremble before Him, then how do you have such blindness of heart? But, you have remained in your evil error; as for us, the new nation, marked with the new blood of the innocent sheep, renovated in the bath of the second birth, may we conduct the gathering of the consecration in the new Temple and cry: "Thou art the Christ, the Son of the Living God, and unto Thee is due glory together with the Father and the Holy Spirit, now and ever and unto ages and ages. Amen. 